Research article

\title{
A modified and improved protocol development for in vitro clonal propagation of Santalum album L. from internodal explants
}

\author{
Parul Bhargava*, N. Ravindra and Gyan Singh
}

State Forest Research Institute, Kanpur, Uttar Pradesh, India

*Corresponding Author: shuklaparul7@gmail.com

[Accepted: 12 July 2018]

\begin{abstract}
Indian sandalwood (Santalum album) is a medium-sized evergreen semi root parasitic tree. It is a commercially important species for its heartwood essential oil, extensively used in medicines, cosmetics, perfume and incense industry. Sandalwood harvesting usually involves removal of the entire tree resulting in critical loss of the genetic diversity. Commercial plantation of the species is not widely done due to nonavailability of good quality planting material in sufficient quantity. Production of sandalwood plantlets through vegetative propagation in regular nurseries is also difficult and time-consuming. Hence, there is a need to develop such planting material/plantlets through tissue culture technique, which provide high yielding clones of candidate plus trees of sandalwood. In the present study, an efficient plant regeneration protocol for in vitro propagation of Santalum album has been developed. Plant propagation using nodal explants was achieved on Murashige and Skoog's (MS) medium. MS solution contains a mixture of macroelement like $\mathrm{NH}_{4}, \mathrm{KNO}_{3}, \mathrm{Mg}, \mathrm{Ca}, \mathrm{KH}_{2}$ and microelements like $\mathrm{Zn}, \mathrm{H}_{3} \mathrm{BO}_{4}, \mathrm{MnSo}_{4}, \mathrm{Cu}$ and $\mathrm{Co}$, sucrose as a source of carbohydrate and vitamins. Effect of plant growth regulators (PGR) like 6-Benzylaminopurine (BAP) and Kinetin (Kn) on shoot induction and multiplication and Indole-3 Butyric acid (IBA) and Naphthalene Acetic acid (NAA) on rooting was studied. Highest shoot multiplication with longest shootlets $(2.90 \mathrm{~cm})$ was achieved on MS medium containing $0.5 \mathrm{mg} \mathrm{L}^{-}$ ${ }^{1} \mathrm{BAP}$ and $5.0 \mathrm{ml} \mathrm{L}^{-1}$ IBA after 30 days of culture. New shoots were repeatedly harvested up to three subculture passages on the fresh medium of same concentration at 4-week intervals. Microshoots treated with $50.0 \mathrm{ml} \mathrm{L}^{-1}$ IBA for $48 \mathrm{~h}$ produced roots on growth regulator free, halfstrength MS medium followed by one-week incubation in the dark. Hence, this protocol is a simple, rapid and highly reproducible to obtain more number of quality plants of Santalum album within a short period.
\end{abstract}

Keywords: Micropropagation - In vitro establishment - Culture medium - Plant growth regulators - Shoot multiplication.

[Cite as: Bhargava P, Ravindra N \& Singh G (2018) A modified and improved protocol development for in vitro clonal propagation of Santalum album L. from internodal explants. Tropical Plant Research 5(2): 193-199]

\section{INTRODUCTION}

India has a rich diversity of forest tree species that have been well known for their utility as well as aesthetic value. Our indigenous species like teak, rosewood, and sandalwood are amongst the most valuable timbers in the word. These trees once abundant in the forests throughout the country have been depleted in recent times to meet the increasing demand for wood plantation (Murlidharan 1997).

Sandalwood or Chandan (Santalum album L.) belongs to the Santalaceae family, a medium-sized evergreen semi root parasitic tree, highly valued for its fragrant heartwood, which contains sandal oil that is used in perfumes, cosmetics, medicine, and also in agarbathi (incense sticks) industries (Srinivasan et al. 1992). Santalum album has the highest oil content (about 6\%) among the species of the genus Santalum. The sandalwood and oil demand (80-90\%) in the international market has been fulfilled by Indian sandalwood for decades. However, the production of sandalwood declined from 4000 tons in 1950 to 2000 tons in 1990 and to about 1000 tons in 1999 (Ananthapadmanabha 2000). The acute shortage in supply and the demand imbalance resulted in the closure of several sandalwood based industries in India and other Asian countries. 
Santalum album is recalcitrant to in vivo and in vitro propagation, for which only limited success has been, achieved so far (Sanjaya et al. 2003). Natural regeneration and artificial propagation occur mainly by seeds. On the other hand, vegetative propagation is accomplished by grafting, air layering, and with root suckers, but the production of clones is insufficient and time-consuming (Srimati et al. 1995).

Previous reports on in vitro propagation have focused on adventitious bud regeneration from in vitro grown seedling explants such as hypocotyl (Bapat \& Rao 1978, Rao \& Bapat 1992), endosperm (Sita et al. 1979), zygotic embryo (Rai \& McComb 2002), and somatic embryogenesis through a callus phase (Sita et al. 1980). Although small numbers of plants were regenerated, the methods are still a long way from being optimized for a large number of plantlet productions. Indeed, the bottleneck is in vitro rooting, which limits the widespread application of micro propagation techniques in sandalwood. There are very few efforts found for in vitro clonal propagation of candidate plus tree (CPT) of S. album through axillary shoot proliferation. Sufficient references on this aspect are also not available. There is, therefore, a need to develop clonal techniques to produce diseaseresistant and high oil-yielding clones of CPTs of Santalum album. The present research study was designed to fill the gap for true to type large scale in vitro plantlet production of Santalum album.

\section{MATERIAL AND METHODS}

\section{Plant material}

The plant materials were collected from healthy, disease-free mature trees of Santalum album, growing in the nursery of State Forest Research Institute (SFRI), Kanpur (Fig. 1). Nodal explants containing axillary buds were mainly selected for in vitro micro propagation of Santalum album $\mathrm{L}$.

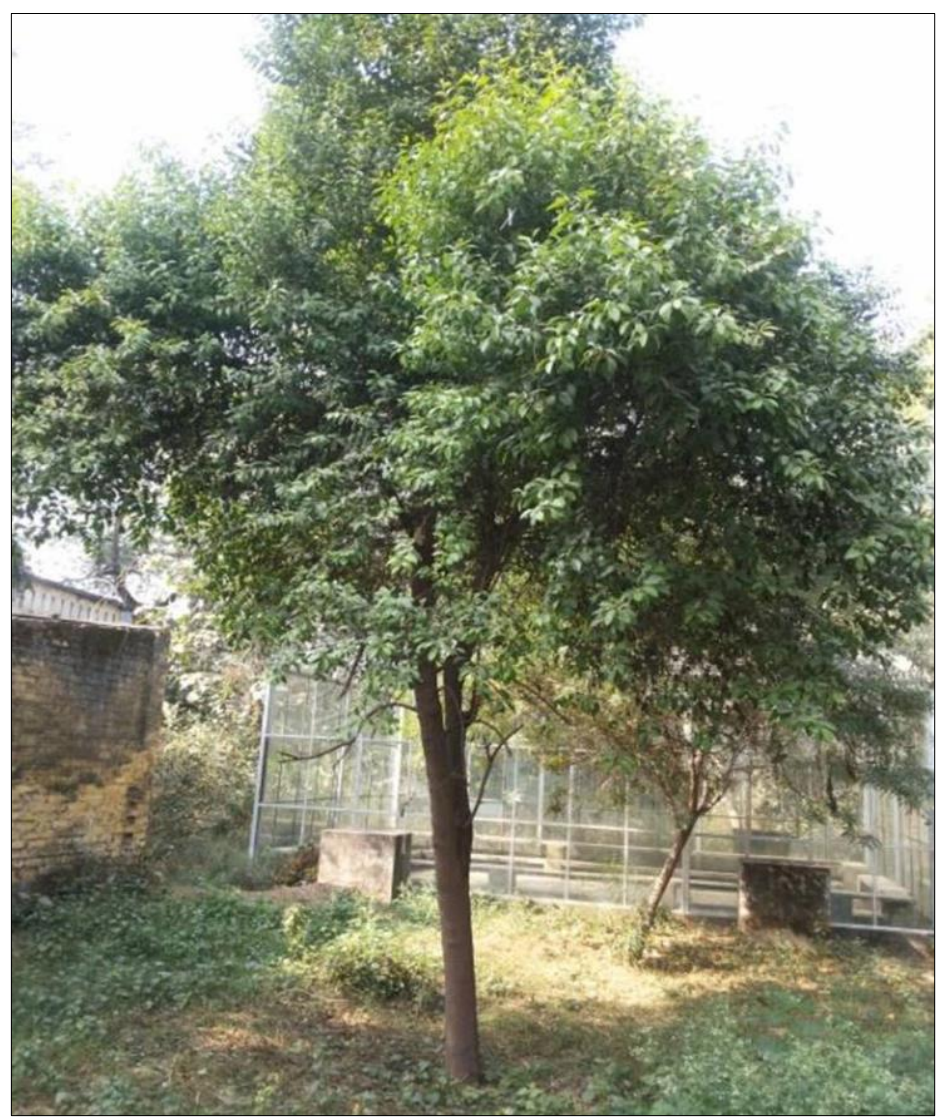

Figure 1. Santalum album L. at State Forest Research Institute (SFRI), Kanpur, Uttar Pradesh, India.

\section{Surface sterilization}

The long shoots obtained from the mother plant after removing the leaves were gently scrubbed with a cotton swab dipped in $70 \%$ alcohol. Cut and trimmed nodal segments containing axillary buds were gently scrubbed all along its length especially around the node bearing the bud (Fig. 2). Explants were sterilized using $0.1 \%$ of Bavistin and $0.1 \%$ paradigm antibiotic solution for removing bacterial contamination and in Mercuric chloride solution at $0.1 \%$ concentration for fungal contamination of each for 5-10 minutes. Surface sterilized explants were thoroughly washed 3-4 times with sterile distilled water to wash off the sterilizing agent. The surface sterilized explants were trimmed at both the ends with the help of scalpel blade and inoculated on Murashige and Skoog's (MS) medium without hormones (Control). 3-4 explants were inoculated in each www.tropicalplantresearch.com 
culture flask. Finally, the cultures were kept in the culture room under controlled conditions and observations recorded regularly.
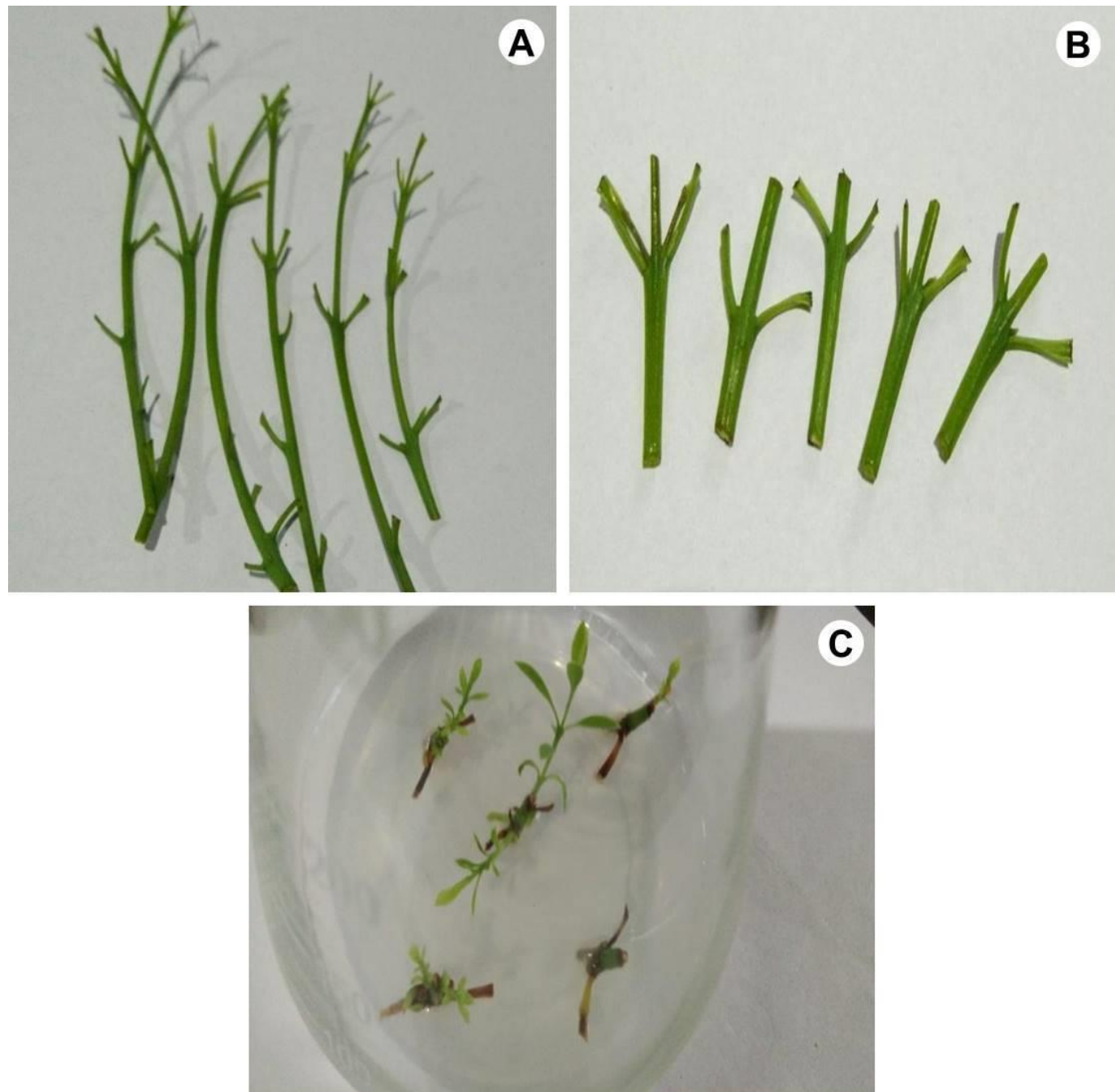

Figure 2. Santalum album L.: A, Surface sterilized nodal explants; B, Surface sterilized trimmed explants; C, Proliferated explants.

Effect of plant growth regulator on shoot development and multiplication

To find out the best auxin and cytokinin effect and their optimum concentration for multiple shoot production and subsequent growth, various concentrations of Indole butyric acid (IBA) and 6benzylaminopurine (BAP) were used in Murashige and Skoog's (MS) medium (Murashige \& Skoog 1962). Nodal shoot segments isolated from in vitro grown shoots on MS medium without hormones (Control) were subcultured on MS medium supplemented with $0.5 \mathrm{mg} \mathrm{l}^{-1}$ BAP and $5 \mathrm{mg} \mathrm{l}^{-1}$ IBA. After four weeks, proliferated shoots higher than $2.0 \mathrm{~cm}$ of original explants were repeatedly subcultured up to five times on Murashige and Skoog's medium containing the mixture of IBA and BAP of same concentration at 4-week intervals. Data were recorded for each subculture cycle.

In vitro root induction in $S$. album

In vitro raised shoots of 3.0-4.0 cm in length were used for in vitro root induction. Micro shoots were pulse treated $(0-72 \mathrm{~h})$ with $50 \mathrm{mg} \mathrm{l}^{-1}$ Indole-3-butyric acid (IBA) and subsequently transferred to half-strength

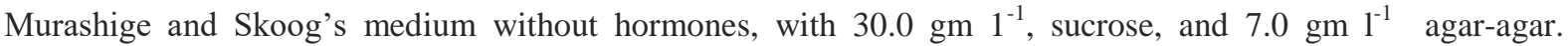
Cultures were incubated in the dark for one week and subsequently shifted to light at $28 \pm 1{ }^{\circ} \mathrm{C}$ with a 16 -h photoperiod provided by cool white fluorescent lamps (Philips, India). The percentage of root induction, number of roots, and root length were recorded at the end of the eighth week.

\section{Pre-hardening and transfer of plantlets to the containers}

In vitro rooted shoots were carefully removed from the culture medium and transferred into 400-ml glass bottles containing the autoclaved soilrite mixture. The transplanted plantlets were maintained at $28 \pm 1{ }^{\circ} \mathrm{C}$ temperature and 16-h photoperiod. The plantlets were sprayed with one-quarter Murashige and Skoog's liquid www.tropicalplantresearch.com 
medium at 15-day intervals to boost the growth of plantlets at pre-hardening. Once adjusted to these initial shocks these plantlets are ready to move out of the laboratory conditions for further stages of growth at acclimatization in germination house.

Data collection and statistical analysis

Each treatment consisted of 5 replications, and each experiment was repeated twice, to confirm the results. The data were analyzed by one-way analysis of variance (ANOVA).

\section{RESULTS}

Shoot initiation

The nodal shoot segments exhibited maximum bud break and the highest number of shoots when cultured on full strength Murashige and Skoog's medium without hormones (Table 1). The nodal shoot segments cultured during November-January yielded maximum bud break (95\%) per explants. Poor shoot development was observed when explants were cultured in May-July on optimum shoot induction medium (Fig. 3).

Table 1. Effect of different concentration of growth hormones in MS medium on bud break of Santalum album L.

\begin{tabular}{lrr}
\hline Nutrient medium & Number of explants inoculated & Bud break/explants \\
\hline MS media without hormones (Control) & $\mathbf{1 0 0}$ & $\mathbf{1 0 0}$ \\
MS + 1ml BAP & 100 & 85 \\
MS + 1.5 ml BAP & 100 & 85 \\
MS + $1 \mathrm{ml} \mathrm{Kn}$ & 100 & 70 \\
MS + $1.5 \mathrm{ml} \mathrm{Kn}$ & 100 & 60 \\
MS + $1 \mathrm{ml} \mathrm{BAP}+1 \mathrm{ml} \mathrm{Kn}$ & 100 & 50 \\
MS + $1.5 \mathrm{ml} \mathrm{BAP}+1.5 \mathrm{ml}+\mathrm{Kn}$ & 100 & 50 \\
\hline
\end{tabular}

Note: Data recorded after 30 days of culture

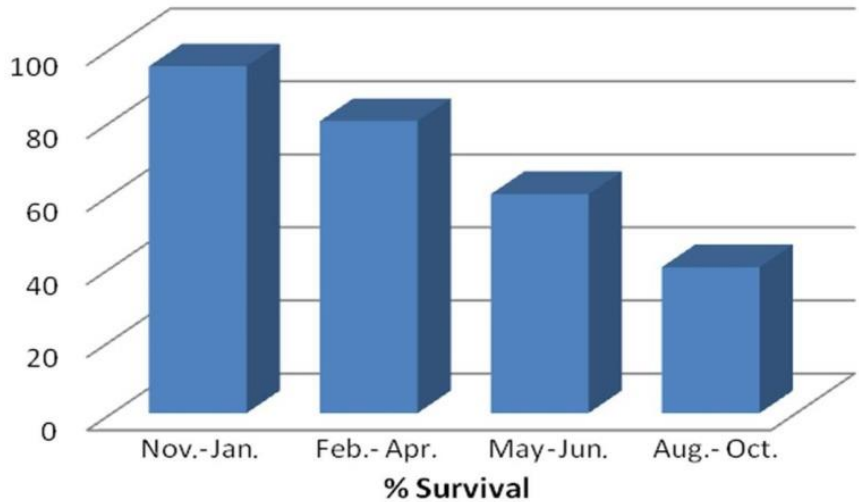

Figure 3. Effect of collection time on the survival of internodeal explants of Santalum album L.

Shoot multiplication

The combined use of BAP $\left(0.5 \mathrm{mg} \mathrm{l}^{-1}\right)$ and IBA $\left(5 \mathrm{mg} \mathrm{l}^{-1}\right)$ significantly enhanced the shoot number per shoot segment (Table 2; Fig. 4A). Subculturing within 4 weeks was essential to maintain healthy shoot growth; moreover, a repeated subculture of the original explant (nodal shoot segment) every 4 weeks on the fresh medium of a mixture of BAP and IBA of same concentration produced a crop of shoots (Fig. 4B). Enhanced rate of shoot multiplication was observed up to the fifth subculture, and the gradual decline was recorded after the fifth subculture.

Table 2. Effect of different concentration of growth hormones in Murashige and Skoog's medium on shoot multiplication and shoot length of Santalum album L.

\begin{tabular}{|c|c|c|}
\hline Nutrient medium & Mean Number of shoots/explants & Mean shoot length $(\mathrm{cm})$ \\
\hline $\mathrm{MS}_{+} 0.1 \mathrm{ml} \mathrm{BAP}+1 \mathrm{ml} \mathrm{IBA}$ & $\begin{array}{ll} & 1.67\end{array}$ & 1.40 \\
\hline $\mathrm{MS}_{+} 0.2 \mathrm{ml} \mathrm{BAP}+2 \mathrm{ml} \mathrm{IBA}$ & 1.75 & 1.40 \\
\hline $\mathrm{MS}_{+} 0.3 \mathrm{ml} \mathrm{BAP}+3 \mathrm{ml} \mathrm{IBA}$ & 1.80 & 1.56 \\
\hline $\mathrm{MS}+0.4 \mathrm{ml} \mathrm{BAP}+4 \mathrm{ml} \mathrm{IBA}$ & 2.00 & 2.00 \\
\hline $\mathrm{MS}+0.5 \mathrm{ml} \mathrm{BAP}+5 \mathrm{ml}$ IBA & 4.00 & 2.90 \\
\hline $\mathrm{MS}+0.1 \mathrm{ml} \mathrm{IBA} \mathrm{+} \mathrm{1ml} \mathrm{BAP}$ & 1.20 & 1.35 \\
\hline $\mathrm{MS}+0.2 \mathrm{ml} \mathrm{IBA}+2 \mathrm{ml} \mathrm{BAP}$ & 1.20 & 1.40 \\
\hline $\mathrm{MS}+0.3 \mathrm{ml} \mathrm{IBA}+3 \mathrm{ml} \mathrm{BAP}$ & 2.00 & 1.50 \\
\hline $\mathrm{MS}+0.4 \mathrm{ml} \mathrm{IBA}+4 \mathrm{ml} \mathrm{BAP}$ & 2.04 & 1.75 \\
\hline $\mathrm{MS}+0.5 \mathrm{ml} \mathrm{IBA}+5 \mathrm{ml} \mathrm{BAP}$ & 2.04 & 1.85 \\
\hline
\end{tabular}

Note: Data recorded after 30 days of culture. 

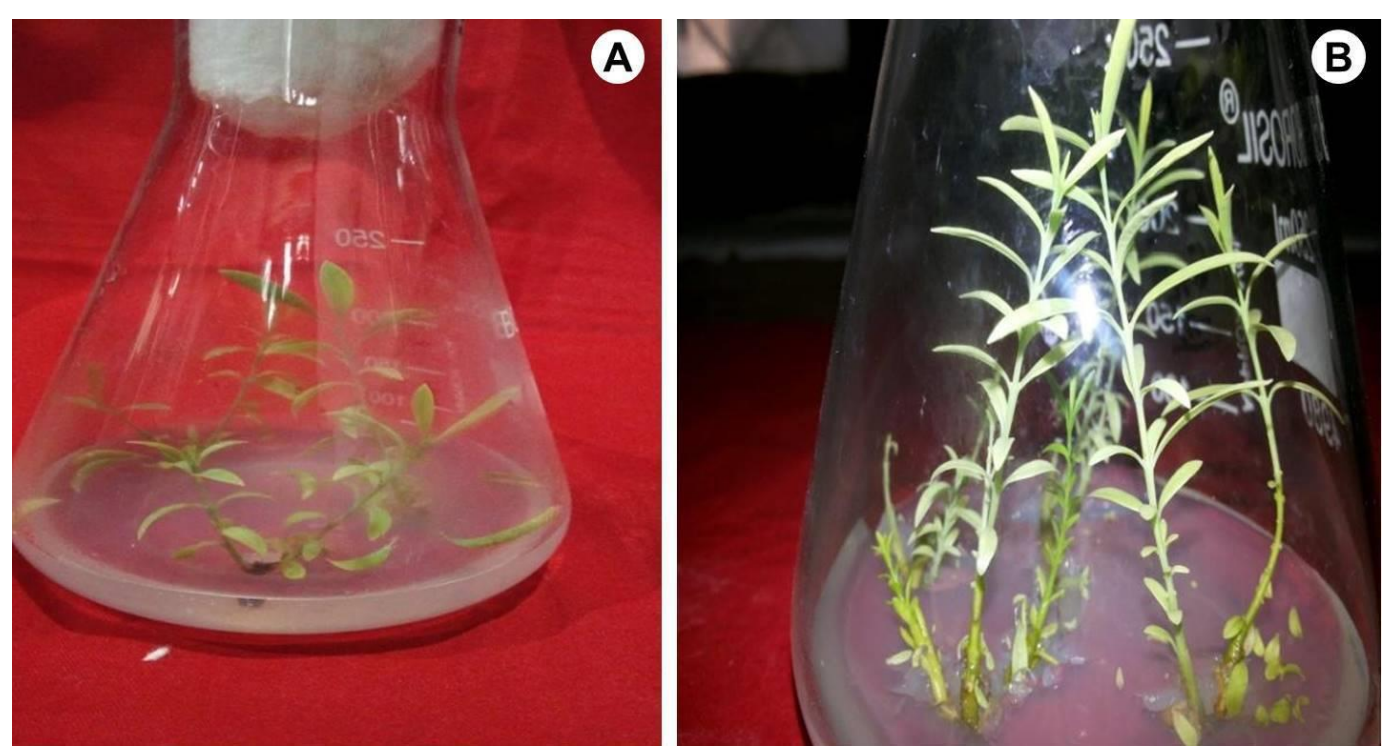

Figure 4. Santalum album L.: A, Development of multiple shoots from nodal shoot; B, Shoot multiplication and elongation during subculture.
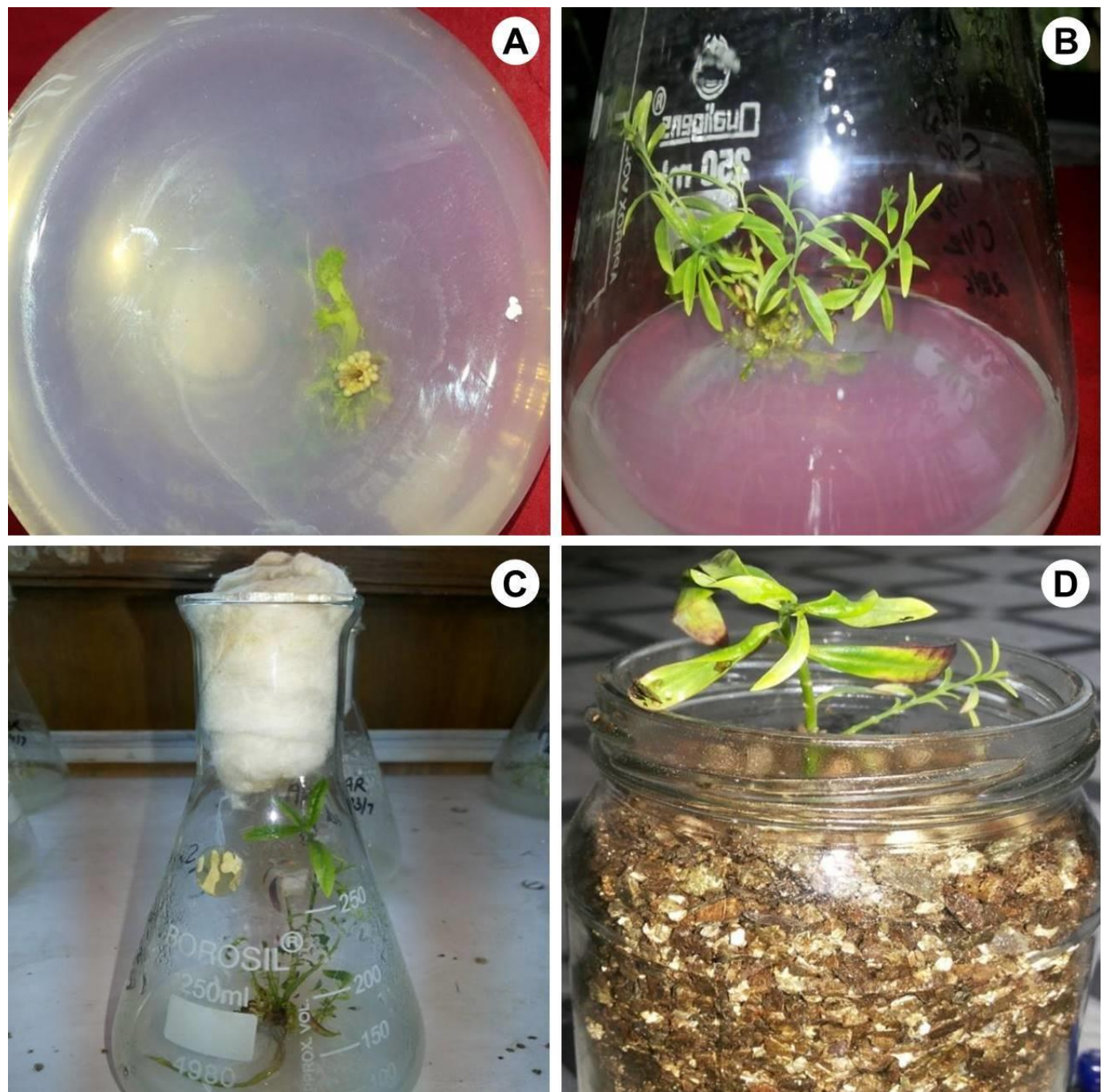

Figure 5. Santalum album L.: A, In vitro rooting of pulse treated shoots after 8 weeks; B, In vitro rooted microshoots; C, Elongation of in vitro root and shoot; $\mathbf{D}$, In vitro microshoots in soilrite.

\section{In vitro rooting}

The duration of pulse treatment had a significant effect on rooting capacity; the best results were obtained with micro shoots treated with $50 \mathrm{ml} \mathrm{l}^{-1}$ IBA for $48 \mathrm{~h}$ and subsequently cultured on half-strength Murashige and Skoog's medium (Table 3; Fig. 5). However, shoots exposed to prolonged pulse treatment leads to necrosis, and no root induction was observed in control. Cultures were incubated in the dark for one week and subsequently www.tropicalplantresearch.com 
shifted to light at $28 \pm 1{ }^{\circ} \mathrm{C}$ with a 16 -h photoperiod provided by cool white fluorescent lamps. Out of the different auxins (IBA, NAA, and IAA) tested, the micro shoots treated with $50 \mathrm{ml} \mathrm{l}^{-1}$ IBA showed maximum rooting $(50 \%)$, and no root induction was noted for IAA and in control without pulse treatment.

Table 3. Effect of duration of pulse treatment of Indole butyric acid $\left(50 \mathrm{ml} \mathrm{l}^{-1}\right)$ on in vitro root induction in Santalum album $\mathrm{L}$.

\begin{tabular}{lrr}
\hline Pulse treatment $(\mathbf{h})$ & Root induction \% & Root length $(\mathbf{c m})$ \\
\hline Control (water) & 00.00 & 00.00 \\
1 & 00.00 & 00.00 \\
5 & 04.16 & 0.15 \\
10 & 08.33 & 0.62 \\
24 & 33.34 & 0.53 \\
$\mathbf{4 8}$ & $\mathbf{5 0}$ & $\mathbf{3 . 3 2}$ \\
72 & 08.16 & 0.45 \\
\hline
\end{tabular}

Note: Data recorded after 30 days of culture.

\section{DISCUSSION}

The use of preexisting buds for propagation reduces the possibility of variation among the progeny and therefore can be safely applied for rapid propagation of field-grown CPTs of sandalwood. We optimized shoot multiplication and novel rooting techniques for mass multiplication of the species without the interference of callus. This method is quite common for the propagation of Fragaria indica (Indre \& Dhar 2000), Acacia mearnsii (Marguerite et al. 2001), Tectona grandis (Mendoza et al. 2007) and Eucalyptus hybrid (Brondani et al. 2011).

The combined use of cytokinin and auxin was emphasized in micropropagation of Ficus carica (Kumar et al. 1998) and Syzygium travancorium (Ajith et al. 1999). The season of explant collection also influenced shoot development from individual explants; this fact may be due to long flowering and seed setting habit of trees.

These observations are in concordance with Sharma et al. (2003) in Crataeva adansoni, where shoot initiation is highly influenced by season. The application of IBA by a pulse treatment was used in adventitious rooting of Maytenus emarginata (Rathore et al. 1992) and Tectona grandis (Siril \& Tewari 1999).

The results obtained in this study are very encouraging and the standardized protocol developed in the course of study will also provide a great opportunity to raise high quality in vitro clonal plantlets of Santalum album. The present investigation will also take another step forward in demonstrating the application of root-trainer technology and compost as a major potting medium ingredient for quality plant production; finally, it will help in the steady establishment of in vitro raised plantlets in field conditions. Because Santalum album is a slowgrowing species, it is too early to evaluate the superiority of in vitro raised plants.

\section{CONCLUSION}

This study provides an efficient in vitro propagation method which could be commercially feasible for Santalum album, by providing a protocol for producing genetically uniform plants from selected genotypes. Explants collected in November to January showed maximum survival and explants inoculated on Murashige and Skoog's media without hormones provided the maximum number of bud break or proliferation.

The concentrations of $0.5 \mathrm{mg} \mathrm{l}^{-1}$ BAP combined with $5 \mathrm{mg} / \mathrm{l}$ IBA on full $\mathrm{MS}$ medium produced mass multiplication and longest shoots. The effect of pulse treatment of $50 \mathrm{mg} \mathrm{l}^{-1}$ IBA on in vitro multiplied shoots for 48 hours followed by transferred in half strength MS media provided a maximum percentage of root induction and root length.

\section{ACKNOWLEDGMENTS}

We wish to thank B.K. Singh, PCCF, Research and Training, and M.P. Singh APCCF / Director, Forest Research Institute, U.P. Kanpur for providing necessary facilities and valuable suggestions during the research study. Ashok Kumar, technical assistant for helping in entire research work and CAMPA, for providing funds.

\section{REFERENCES}

Ajith A, Srinivasa Rao C \& Balakrishna P (1999) In vitro propagation of Syzygium travancoricum Gamble - an endangered tree species. Plant Cell, Tissue and Organ Culture 56: 59-63.

Ananthapadmanabha HS (2000) Sandalwood and its marketing trend. My Forest 36: 147-152.

Bapat VA \& Rao PS (1978) Vegetative propagation of sandalwood plants through tissue culture. Canadian Journal of Botany 56: 1153-1156.

Brondani GE, Dutra LF, Wendling I, Grossi F, Hansel FA \& Araujo MA (2011) Micropropagation of an 
Eucalyptus hybrid (Eucalyptus benthamii x Eucalyptus dunnii). Acta Scientiarum Agronomy 33: 655-663.

Indre DB \& Dhar U (2000) Micropropagation of Indian wild strawberry. Plant Cell, Tissue and Organ Culture 60: 83-88.

Kumar V, Radha A \& Goh CJ (1998) In vitro plant regeneration of fig (Ficus carica L. cv Gular) using apical buds from mature trees. Plant Cell Reports 17: 717-720.

Marguerite Q, Silva MC, Kelly G \& Oliveira ED (2001) Multiplication of juvenile black wattle by micro cuttings. Plant Cell, Tissue and Organ Culture 66: 199-205.

Mendoza E, Royani JI \& Rugini E (2007) Efficient method of micropropagation and in vitro rooting of teak (Tectona grandis L.) focusing on large - scale industrial plantations. Annals of Forest Science 64: 73-78.

Murashige T \& Skoog F (1962) A revised medium for rapid growth and bioassay with tobacco tissue cultures. Physiologia Plantarum 15: 473-497.

Murlidharan EM (1997) Micropropagation of Teak, Rosewood and Sandal. KFRI Research Report, pp. 119.

Rai RV \& McComb J (2002) Direct somatic embryogenesis from mature embryos of sandalwood. Plant Cell, Tissue and Organ Culture 69: 65-70.

Rao PS \& Bapat VA (1992) Micropropagation of Sandalwood (Santalum album L.). In: Bajaj YPS (ed) Biotechnology in agriculture and forestry, high-tech and micropropagation II, vol 18. Springer, Berlin Heidelberg New York, pp. 193-210.

Rathore TS, Deora NS \& Shekhawat NS (1992) Cloning of Maytenus emarginata (Wild) Ding Hou - a tree of the Indian desert, through tissue culture. Plant Cell Reports 11: 449-451.

Sanjaya, Anathapadmanabha HS \& Rai VR (2003) In vitro and in vivo micrografting of Santalum album shoot tips. Journal of Tropical Forest Science 15: 234-236.

Sharma PK, Purnima T, Sharma KC \& Kothari SL (2003) Clonal micropropagation of Crataeva adansoni (DC.) PRODR.: a multipurpose tree. In Vitro Cellular \& Developmental Biology - Plant 39: 156-160.

Siril EA \& Tewari SK (1999) A method for the synchronization of rooting and hardening of micropropagated shoots of Teak (Tectona grandis L.) under ex vitro conditions. Journal of Tropical Forestry 15: 229-232.

Sita LG, Raghava Ram NV \& Vaidyanathan CS (1979) Differentiation of embryoids and plantlets from shoot callus of sandalwood. Plant Science Letters 15: 265-270.

Sita LG, Raghava Ram NV \& Vaidyanathan CS (1980) Triploid plants from endosperm culture of sandalwood by experimental embryogenesis. Plant Science Letters 20: 63-69.

Srimati RA, Venkateshan KR \& Kulkarni HD (1995) Guidelines for selection and establishment of seed stands, seed production areas, plus trees and clonal seed orchards for sandal (Santalum album L.). In: Srimati RA, Venkateshan KR \& Kulkarni HD (eds) Recent advances in research and management of sandal (Santalum album L.) in India. New Delhi, pp. 281-299.

Srinivasan VV, Sivaramakrishnan K, Rangaswamy CR, Ananthapadmanabha HS \& Shankara Narayana KH (1992) Sandal (Santalum album L.). Institute of Wood Science and Technology, Bangalore, India, pp. 1-60. 